\title{
Investigation of the Effects of Bisphenol A on the Histology and Ultrastructure of Prostate and Seminal Vesicle Glands in Rats
}

\author{
Elham Asgari Hasanluyi, ${ }^{1,}$ Seyed Mahdi Banan Khojasteh, ${ }^{1}$ and Daryoush Mohammad Nejhad ${ }^{2}$ \\ ${ }^{1}$ Department of Animal Biology, Faculty of Natural Sciences, University of Tabriz, Tabriz, Iran \\ ${ }^{2}$ Drug Applied Research Center, Tabriz University of Medical Sciences, Tabriz, Iran \\ "Corresponding author: Elham Asgari Hasanluyi, Department of Animal Biology, Faculty of Natural Sciences, University of Tabriz, Tabriz, Iran. Tel: +98-9147261006, E-mail: \\ E.asgari87@gmail.com
}

Received 2016 May 10; Revised 2016 October 08; Accepted 2016 November 05.

\begin{abstract}
Background: Bisphenol A is a xenoestrogen, synthesized in large quantities for the production of polymers (polycarbonates, epoxy resins) and thermal paper, and is widely used in products of everyday use (packaging, containers and bottles). Data concerning the occurrence of BPA in food, water and indoor environments as well as its appearance in tissues and body fluids of the human body are available in the literature. Male accessory sex glands are also vulnerable to environmental endocrine disruptors with adverse effects in adulthood. The developing prostate gland is particularly sensitive to estrogens and high-dose exposures during a critical developmental window results in intraepithelial prostatic neoplasia (PIN) in adult rodent models. Bisphenol A is also an endocrine disruptor. High levels of BPA exposure correlate with increased risk of mammary gland, brain and prostate cancers and have adverse effects on the tissues of the prostate and seminal vesicles.

Objectives: The aim of this study was to investigate the effects of BPA doses on the histological structure and ultrastructure of prostate and seminal vesicle glands.

Methods: Forty male Wistar rats were randomly divided into four groups $(n=10)$ : A control group and three treatment groups, receiving BPA at doses of 10,50 and $100 \mu \mathrm{g} / \mathrm{kg}$. Bisphenol A was administrated intraperitoneally for 15 days. As the prostate and seminal vesicle glands were dissected on the day 16 , the structure and ultrastructure histological parameters were analyzed, using light and electron microscopes.

Results: The main pathological finding observed in the prostrate and seminal vesicle glands, using light microscope, revealed congestion in the connective tissue and vacuolization in the secretory units of epithelial cells and epithelium rupture at 50 and 100 $\mu \mathrm{g} / \mathrm{kg}$ doses of BPA. Ultrastructure study showed vacuolization of mitochondria, condensation of nuclei and disappearance of nucleus in the prostate tissue. Pathological changes showed the vacuolization and dilation of endoplamic reticulum(ER)and secretory glands and disappearance of microvilli. They also showed an increase in collagen fibers around the cells in the seminal vesicle tissue in the treatment group that received $100 \mu \mathrm{g} / \mathrm{kg}$ BW BPA.

Conclusions: This study revealed that BPA has adverse effects on the reproductive system in male rats. The results also revealed that BPA has destructive effects on the prostate and seminal vesicle glands.
\end{abstract}

Keywords: Bisphenol A, Reproductive System, Prostate, Seminal Vesicle, Male Wistar Rats

\section{Background}

Endocrine disrupting chemicals (EDC) are environmental compounds that arise from many different sources and act as hormone mimics to disrupt normal endocrine function. They lead to altered sexual development and reproduction in both sexes of human and wild life animals (1$4)$. One of these endocrine disrupting chemicals is Bisphenol A (BPA). BPA is used extensively in the industry and commerce to manufacture polycarbonate plastics. These plastics can be used in baby bottles, water storage tanks, or supply pipes (5). It is also used to make epoxy resins, electronics, medical equipments, and dental sealants (6, 7). The human population is frequently exposed to BPA through various sources. For instance, BPA can leach from the inner lining of tin cans and microwave containers into the food materials during heating (8) and from dental sealants into saliva (9) and from polycarbonate bottles into beverages due to repeated usage or contact with any acidic/alkaline contents (10).

This shows weak binding affinity to the estrogen receptors (ER) and scant estrogenic activity when measured using the yeast two-hybrid assay and antagonist for the androgen (11, 12), thyroid (13), and aryl hydrocarbon receptors (11). Reproductive physiology involves complex biological processes that can be disrupted when exposed to environmental contaminants (14). The male accessory sex glands of mammals include the prostate gland, the vesicular glands, the glands of the ampulla and the bulbourethral glands. These glands work by androgen, and 
play an important role in the reproductive function $(15,16)$.

The appearance of BPA in tissues and fluids of the human body has adverse effects on the male reproductive system. Significant damages to the acrosomes, the plasma membrane with reduced mitochondrial activity, and increased levels of defective spermatozoa may have compromised sperm functions, and may cause faster movement through epididymis BPA exposure, reducing the serum concentrations of testosterone, $\mathrm{LH}$ and FSH and increasing the concentration of estradiol (14). The accumulation of DNA damage in germ cells was induced by BPA exposure via oxidative stress (17). Exposing the adult male rats to BPA resulted in the decrease of testicular weight, daily sperm production and efficiency of spermatogenesis (18). Furthermore, prenatal exposure of pregnant rats to BPA causes breast cancer in adult female offsprings and hyperplasia of prostate in male rats, and this hyperplasia may result in greater risk of prostate cancer (19).

In humans, BPA also reduced sperm concentration, motility and morphology (17). High levels of BPA exposure, correlated with increased risk of mammary gland and prostate cancers have negative effects on the tissues of prostate and seminal vesicles glands.

\section{Objectives}

The aim of this study was to investigate the effects of BPA doses on the histological structure and ultrastructure of prostate and seminal vesicle glands.

\section{Methods}

\subsection{Animals and Treatments}

In this study, 40 four-week-old male Wistar rats (200 $250 \mathrm{gr}$ ) were obtained from the experimental animal center of Urmia university. They were maintained in a controlled environment temperature and on a 12/12 light/dark cycle (lights on 7:00 am), with free access to rat chow and water. After two weeks of acclimatization period, the mice were randomly assigned into one control and three treatment groups, $(\mathrm{n}=10)$, each receiving BPA at doses of 10-50$100 \mu \mathrm{g} / \mathrm{kg}$, which was dissolved in ethanol and water for stock solution in 15 consecutive days or only in ethanol as a vehicle control during the same period. Bisphenol A was administrated intraperitoneally for 15 days.

\subsection{Chemicals}

Bisphenol A was obtained from Merck Co. Other chemicals such as ethanol 96\% were used in this study as solvent.

\subsection{Light Microscopic Analysis}

The prostate and vesicular glands were dissected out, and tissue samples were fixed by immersion in 10\% formalin. Then, the samples were dehydrated in graded ethanol, cleared in xylen, and impregnated and embedded in paraffin wax. Sections of $6-7 \mu$ thick were obtained, utilizing Leitz microtome model 1512 and stained with hematoxylin/eosin (H \& E) (20). All the slides were examined and photographed, using an Olympus BH-2 light microscope to be assessed by the histological features.

\subsection{Electron Microscopic Analysis}

For electron microscopy, prostate and vesicle seminal tissues were fixed for 10 - 30 minutes in acrolein and for two to six hours in a mixture of glutaraldehyde (2.5\%) and paraformaldehyde (4\%). They were then washed and stored. Furthermore, small blocks $(1 \mathrm{~mm})$ were cut from the large blocks and were used for ordinary frozen sections. The pieces were washed in graded series of ethanol (21). They were embedded, using pure resin and ultrathin sections and were stained with uranyl-acetate and lead citrate (22). The sections were examined with a LEO 906 transmission electron microscope (21).

\section{Results}

\subsection{Light Microscopy}

These observations revealed pathological changes in the prostate and seminal vesicle tissue, at doses of 50 and $100 \mu \mathrm{g} / \mathrm{kg}$ of BPA.

\subsection{Prostate Analysis}

After examining the prostate gland, using a light microscope, we found that the structure of this gland consists of the matrix and parenchyma, formed by the tissue connected to nerves, blood vessels and smooth muscle fibers. Prostate epithelium is simple or pseudo-stratified columnar. It has alveolar and tubular secretory units, and a loose connective tissue, which can be seen between secretory units (Figure $1 \mathrm{~A}$ and $\mathrm{B}$ ).

After examining the rats treated with BPA at dose of 100 $\mu \mathrm{g} / \mathrm{kg}$, we found congestion in the blood vessels of the connective tissue, and this change could result in tissue destruction (Figure $2 \mathrm{~A}$ and $\mathrm{B}$ ).

Administrated BPA at dose of $50 \mu \mathrm{g} / \mathrm{kg}$ showed rupture in epithelium of the secretory units compared to the control group. In addition, epithelium lost its integrity in the treated group (Figure 3). 


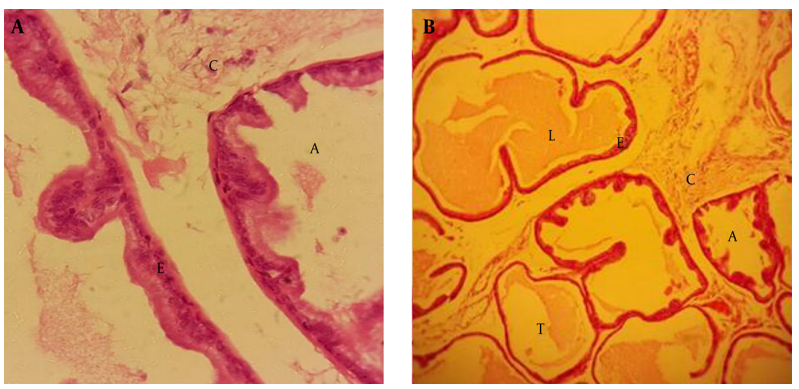

Figure 1. $\mathrm{A}(\mathrm{H} \& \mathrm{E} \times 10)$ and $\mathrm{B}(\mathrm{H} \& \mathrm{E} \times 40)$ : The Cross Section of Prostate Gland in the Control Group; Simple Clumnar Epithelium (E), Secretory Units (A and T), Connective Tissue Between Secretory Units (C), Lumen (L)
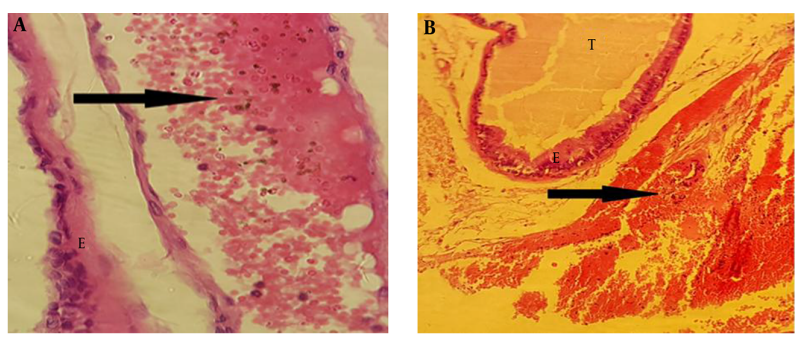

Figure 2. A and B: The Cross Section of the Prostate Tissue in the Treatead Group, with BPA at $100 \mu \mathrm{g} / \mathrm{kg}$, Revealed Congestion (Arrows), Epithelium (E), and Secretory Units (T)

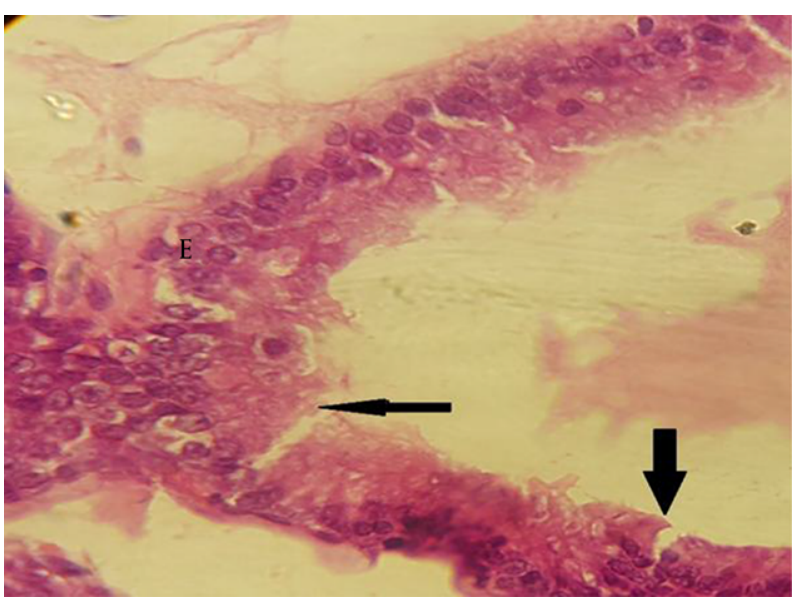

Figure 3. The Cross Section of Prostate Tissue in Treated Group with BPA at $50 \mu \mathrm{g} / \mathrm{kg}$, Showed Rupturs (Arrows) in Epithelium of the Secretory Units $(\mathrm{H} \& \mathrm{E} \times 400)$

\subsection{Vesicle Seminal Analysis}

Examination of the vesicle seminal gland by a light microscope demonstrated that this gland includes mucous with many complex and thin folds covered by simple or pseudo-stratified columnar epithelium. Muscle layer was formed by smooth and circular muscles, and lumen that contained semen secretion (Figure $4 \mathrm{~A}$ and $\mathrm{B}$ ).
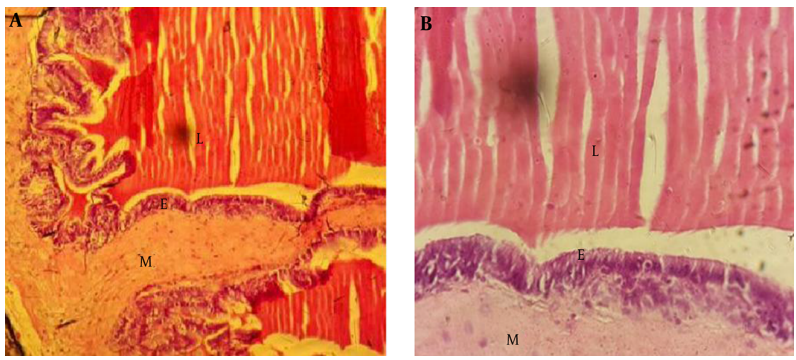

Figure 4. $A(H \& E \times 40)$ and $B(H \& E \times 100)$ : The Cross Section of Vesicle Seminal Gland in Control Group. Pseudostratilied Clumnar Epithelium (E), Connective Tissue $(C)$, and Lumen $(L)$ are Seen

In the treated groups with BPA at dose of $100 \mu \mathrm{g} / \mathrm{kg}$, rupture was observed in epithelium of the folds in comparison to the control group. Epithelium lost its integrity in the treated groups (Figure 5).

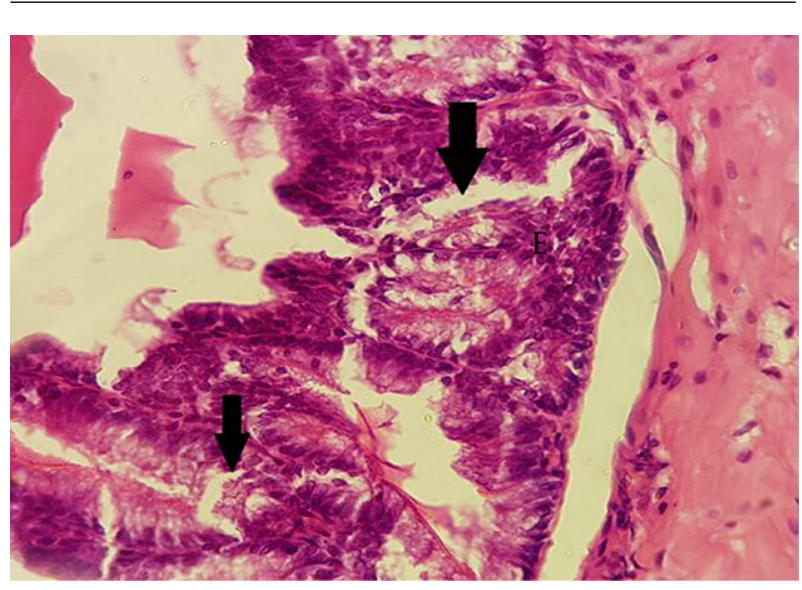

Figure 5. The Cross Section of Vesicle Seminal Gland in Treated Group with BPA at $100 \mu \mathrm{g} / \mathrm{kg}$, Rupturs (Arrows) Were Seen in Epithelium of the Folds Compared with the Control Group $(\mathrm{H} \& \mathrm{E} \times 400)$

\subsection{Electron Microscopy}

\subsubsection{Prostate Analysis}

Using electron microscope, we could see cell organelles such as nuclei, nucleus, mitochondria and endoplasmic reticulum in the prostate tissue of the control group (Figure 6A and B).

In the treated rats with BPA at dose of $100 \mu \mathrm{g} / \mathrm{kg}$, we observed the nuclei condensation and nucleus disappearance in cells of the prostate tissue in comparison with the control group; and the cells lost their activity (Figure 7).

In the mitochondria of the treated group with BPA at dose of $100 \mu \mathrm{g} / \mathrm{kg}$, we observed vacuolization (Figure 8B) in 


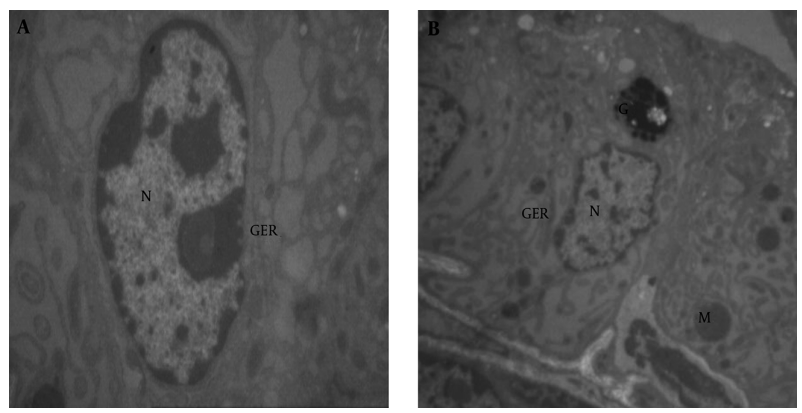

Figure 6. A $(\times 3597)$ and $B(\times 1670)$ : Epithelial Cells of the Prostate in the Contro Group including (M) Mitochondria, (N) Nuclei, (GER) Granular Endoplasmic Reticolum

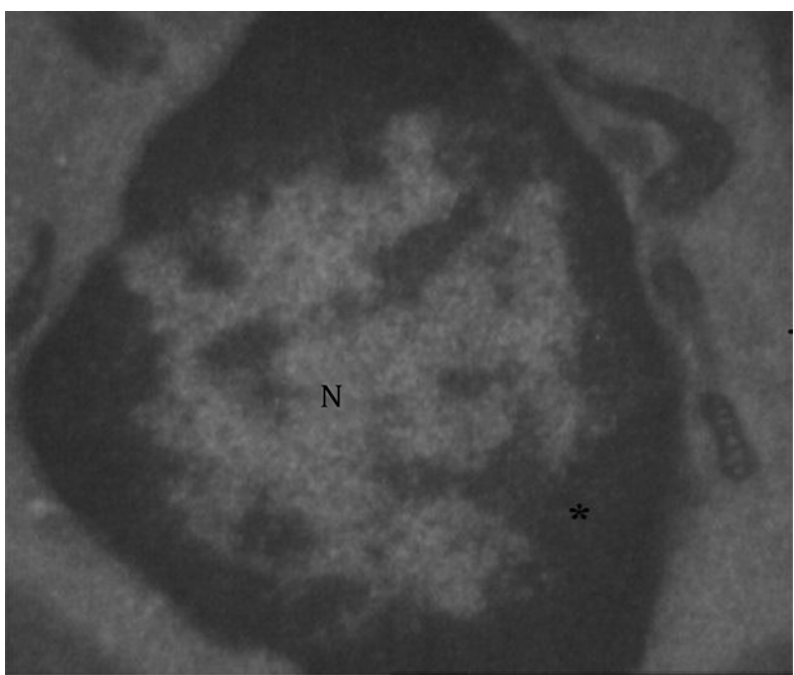

Figure 7. Nuclei $(\mathrm{N})$ in Epithelial Cells Were Condensed in the Treated Rats with BPA at $100 \mu \mathrm{g} / \mathrm{kg}(\times 10000)$

comparison with mitochondria of the control group (Figure $8 \mathrm{~A})$.

\subsubsection{Seminal Vesicle Analysis}

Normal tissues of the vesicle seminal in the control group included microvilli, nuclei, nucleus and other cellular organelles (Figure 9A). The microvilli of the treated group with BPA at dose of $100 \mu \mathrm{g} / \mathrm{kg}$ disappeared (Figure 9B).

Normal endoplasmic reticulum in seminal vesicle(Figure 10) showed vacuolated reticulum (star and ER) endoplasmic around the nucleus $(\mathrm{N})$ in the treated group, with 100 at $100 \mu \mathrm{g} / \mathrm{kg}$ dose (Figure 11).

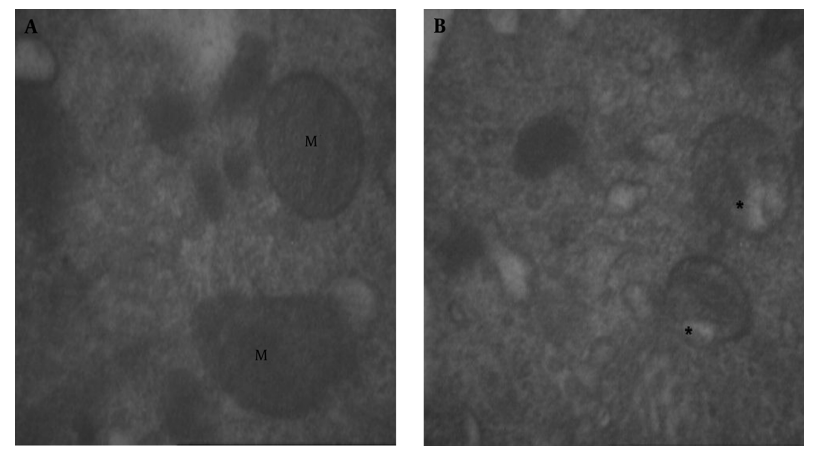

Figure 8. A, The Normal Mitochondria $(M)$ in the Control Group ( $\times$ 21560); B, In Mitochondries of the Treated Group with BPA at $100 \mu \mathrm{g} / \mathrm{kg}$, Vacoulization (star) Was Seen $(\times 16700)$
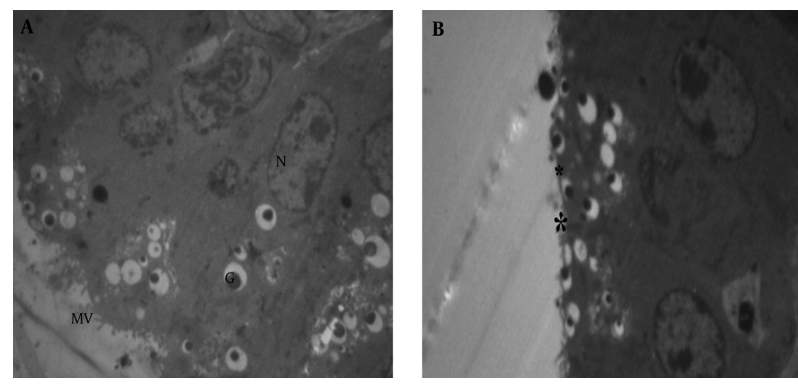

Figure 9. A $(\times 1670)$, The normal tissue of the vesicle seminal gland BPA in control group included: Microvilli (MV), Nuclei $(\mathrm{N})$, and other celluar organells; $\mathrm{B}(\times 1293)$, The microvilli (star) of the treated group with $100 \mu \mathrm{g} / \mathrm{kg}$ were disappeared.

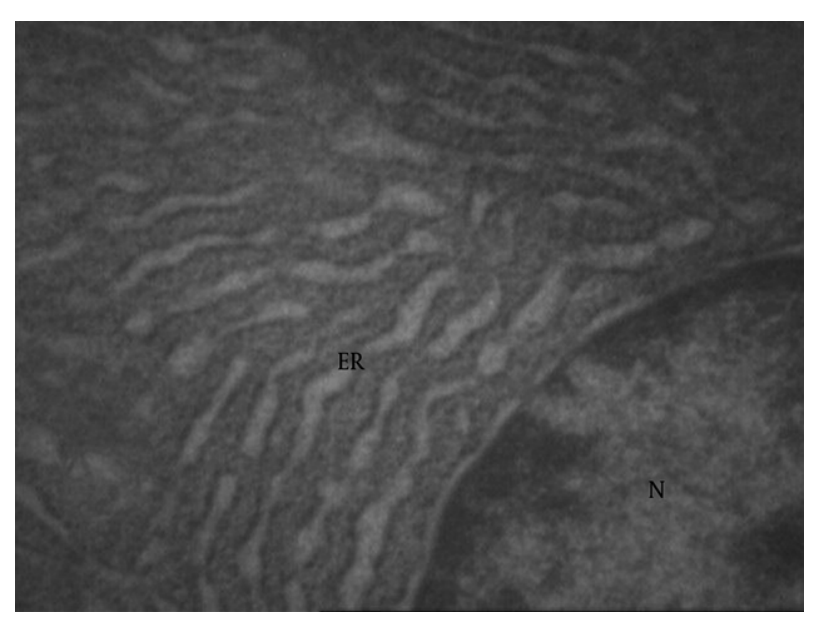

Figure 10. Normal Endoplasmic Reticolum in Seminal Vesicle (ER), (N) Nuclei ( $X$ 1291)

\section{Discussion}

Bisphenol A (BPA) is a xenoestrogen, synthetized in large quantities to produce polymers and thermal paper, 


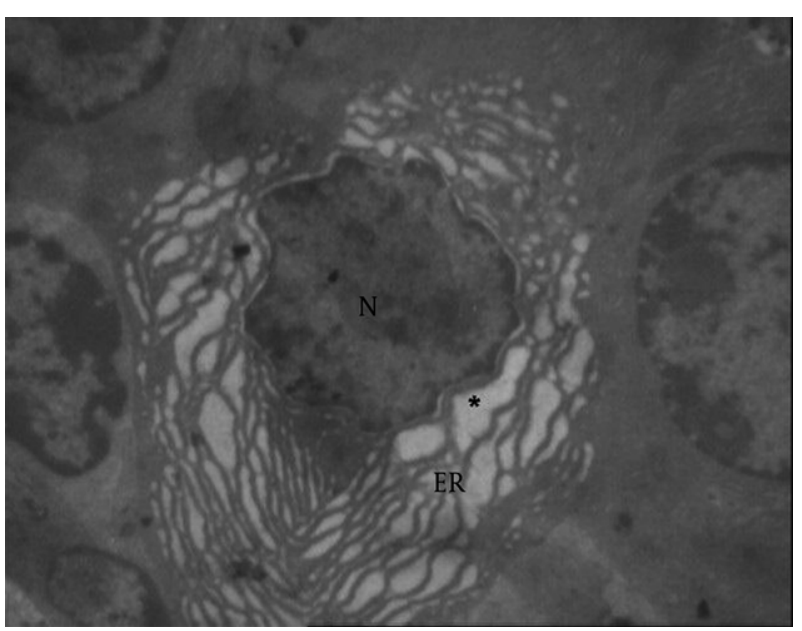

Figure 11. The Treated Group with 100 at $100 \mu \mathrm{g} / \mathrm{kg}$ Showed Vacuolated Reticulum (Star and ER) Endoplasmic Around the Nucleus $(\mathrm{N})(\times 2784)$

with a widespread use in manufacturing the products of everyday use. Data exist on BPA occurrence in food, water and indoor environments as well as its appearance in tissues and human body fluids. Bisphenol $\mathrm{A}$ is also an endocrine disruptor.

In this study, we administered Bisphenol A at doses of $10,50,100 \mu \mathrm{g} / \mathrm{kg}$ of body weight to the rats and detected pathological changes in both the structure and the ultrastructure study of prostate and seminal vesicle. These observations conducted on the prostate and seminal vesicle glands revealed congestion in the connective tissue, vacuolization in the epithelium of the secretory units and epithelium rupture at doses of 50 and $100 \mu \mathrm{g} / \mathrm{kg}$ of BPA. Ultra structure study of the prostate and seminal vesicle tissue demonstrated vacuolization of mitochondria, nuclei condensation and nucleus disappearance in the prostate tissue, vacuolization and dilation of ER and secretory glands. It also revealed the disappearance of microvilli and an increase in collagen fibers around the nuclei in the seminal vesicle in the treated group with BPA at dose of $100 \pi \mathrm{g} / \mathrm{kg}$ compared to the control group. This result revealed that BPA has destructive effects on the prostate and seminal vesicle glands. It also showed that BPA has adverse effects on the reproductive system in male rats.

BPA is reported to have both estrogenic and antiandrogenic effects $(6,23,24)$. Several toxicological studies (25) pointed out that rodents exposed to BPA during the prenatal or perinatal period show a large variety of adverse reproductive outcomes, including decreased epididymal weight and daily sperm production $(26,27)$ and increased prostate weight (28), which is somewhat similar to our findings. With respect to the prepubertal or pubertal exposures, rodent studies have described a dramatic decrease in testosterone (T) levels $(29,30)$ and epididymal sperm counts (29) after BPA exposure. After being exposed to BPA at a dose of 25 or $100 \mathrm{ng} / \mathrm{kg}$, adult male mice showed a significant reduction in testicular as well as epididymal sperm counts (31). Tohei et al. (2001) (32) reported that plasma concentrations of $\mathrm{T}$ were decreased and plasma concentrations of luteinizing hormone (LH) were increased in male adult rats, which were treated in different doses of BPA, compared to the rats in the control group.

This xenoestrogen is able to bind and activate both ERa and ERb (23) and is shown to suppress androgen production by rat Leydig cells in vivo and in vitro (33). However, the direct effects of BPA on androgen production, using developing mouse Leydig cells with different capacities, have not been investigated yet. Prepubertal Leydig cells produce androgens that play an important role in the initiation and maintenance of spermatogenesis as well as the regulation of multiple androgen-dependent physiological processes in the developing body (34).

The effect of low doses of Bisphenol A on male reproduction is controversial. Ema et al. (2001) (35) reported that administration of Bisphenol $\mathrm{A}$ at doses of $0.2 / 200 \mathrm{mg} / \mathrm{Kg}$ body weight per day did not cause significant changes in the reproductive parameters of the rats for two generations; however, our study showed that low doses of Bisphenol A caused reproductive toxicity.

Moreover, vitro and animal studies show that BPA exposure can increase the risk of mammary gland, brain, and prostate cancers (36). However, human studies linking BPA exposure to heightened cancer risk are scarce. Chronic long-term exposure of high-dose of estrogenic substances leads to squamous metaplasia of the prostate, which involves multi layering of the basal epithelial cells and expression of cytokeratin 10 (CK10) (37). Nevertheless, numerous findings suggest that BPA adversely affects the male reproductive system. Tohei et al. (32) showed that Bisphenol A inhibits testicular function in adult male rats. In mice, testicular hypotrophy and decreased daily sperm production were observed in the presence of $\operatorname{BPA}(31,38)$. In humans, BPA also reduced sperm concentration, motility and morphology (39). BPA exposure may also induce apoptosis in rat germ cells in vivo (40) and in cultured rat Sertoli cells (41), and has the potential to redistribute several known Sertoli cell junctional proteins $(42,43)$. Subsequent studies also demonstrated that BPA is genotoxic. The accumulation of DNA damage in germ cells was induced by being exposed to BPA via oxidative stress (43). 


\section{Acknowledgments}

The authors would like to thank the Faculty of Natural Sciences of University of Tabriz for their support.

\section{Footnote}

\section{Funding/Support: University of Tabriz.}

\section{References}

1. Cederroth CR, Zimmermann C, Nef S. Soy, phytoestrogens and their impact on reproductive health. Mol Cell Endocrinol. 2012;355(2):192200. doi: 10.1016/j.mce.2011.05.049. [PubMed: 22210487].

2. Fowler PA, Bellingham M, Sinclair KD, Evans NP, Pocar P, Fischer $B$, et al. Impact of endocrine-disrupting compounds (EDCs) on female reproductive health. Mol Cell Endocrinol. 2012;355(2):231-9. doi: 10.1016/j.mce.2011.10.021. [PubMed: 22061620].

3. Nordkap L, Joensen UN, Blomberg Jensen M, Jorgensen N. Regional differences and temporal trends in male reproductive health disorders: semen quality may be a sensitive marker of environmental exposures. Mol Cell Endocrinol. 2012;355(2):221-30. doi: 10.1016/j.mce.2011.05.048. [PubMed: 22138051].

4. Virtanen HE, Adamsson A. Cryptorchidism and endocrine disrupting chemicals. Mol Cell Endocrinol. 2012;355(2):208-20. doi: 10.1016/j.mce.2011.11.015. [PubMed: 22127307].

5. Vandenberg LN, Maffini MV, Sonnenschein C, Rubin BS, Soto AM. Bisphenol-A and the great divide: a review of controversies in the field of endocrine disruption. Endocr Rev. 2009;30(1):75-95. doi: 10.1210/er.2008-0021. [PubMed: 19074586].

6. Wetherill YB, Akingbemi BT, Kanno J, McLachlan JA, Nadal A, Sonnenschein C, et al. In vitro molecular mechanisms of bisphenol A action. Reprod Toxicol. 2007;24(2):178-98. doi: 10.1016/j.reprotox.2007.05.010. [PubMed: 17628395].

7. Pflieger-Bruss S, Schuppe HC, Schill WB. The male reproductive system and its susceptibility to endocrine disrupting chemicals. Andrologia. 2004;36(6):337-45. doi:10.1111/j.1439-0272.2004.00641.x. [PubMed: 15541049].

8. Brotons JA, Olea-Serrano MF, Villalobos M, Pedraza V, Olea N. Xenoestrogens released from lacquer coatings in food cans. Environ Health Perspect. 1995;103(6):608-12. [PubMed: 7556016].

9. Olea N, Pulgar R, Perez P, Olea-Serrano F, Rivas A, Novillo-Fertrell A, et al. Estrogenicity of resin-based composites and sealants used in dentistry. Environ Health Perspect. 1996;104(3):298-305. [PubMed: 8919768].

10. Biles JE, McNeal TP, Begley TH, Hollifield HC. Determination of bisphenol-A in reusable polycarbonate food-contact plastics and migration to food-simulating liquids. J Agric Food Chem. 1997;45(9):3541-

11. Bonefeld-Jorgensen EC, Long M, Hofmeister MV, Vinggaard AM. Endocrine-disrupting potential of bisphenol A, bisphenol A dimethacrylate, 4-n-nonylphenol, and 4-n-octylphenol in vitro: new data and a brief review. Environ Health Perspect. 2007;115 Suppl 1:69-76. doi: 10.1289/ehp.9368. [PubMed: 18174953].

12. Sun $\mathrm{H}, \mathrm{Xu} \mathrm{XL}$, Xu LC, Song L, Hong X, Chen JF, et al. Antiandrogenic activity of pyrethroid pesticides and their metabolite in reporter gene assay. Chemosphere. 2007;66(3):474-9. doi: 10.1016/j.chemosphere.2006.05.059. [PubMed: 16857237].

13. Moriyama K, Tagami T, Akamizu T, Usui T, Saijo M, Kanamoto N, et al. Thyroid hormone action is disrupted by bisphenol A as an antagonist. J Clin Endocrinol Metab. 2002;87(11):5185-90. doi: 10.1210/jc.2002020209. [PubMed: 12414890].
14. Wisniewski P, Romano RM, Kizys MM, Oliveira KC, Kasamatsu T, Giannocco G, et al. Adult exposure to bisphenol A (BPA) in Wistar rats reduces sperm quality with disruption of the hypothalamic-pituitarytesticular axis. Toxicology. 2015;329:1-9. doi: 10.1016/j.tox.2015.01.002. [PubMed: 25575453].

15. Adebayo AO, Oke BO, Akinloye AK. The gross morphometry and histology of the male accessory sex glands in the greater cane rat (Thryonomys swinderianus, Temminck).J Veterinary Anatomy. 2009;2:41-51.

16. Aughey E, Frye F. Comparative veterinary histology. Manson Publishing; 2001.

17. Ali S, Steinmetz G, Montillet G, Perrard MH, Loundou A, Durand P, et al Exposure to low-dose bisphenol A impairs meiosis in the rat seminiferous tubule culture model: a physiotoxicogenomic approach. PloS one. 2014;9(9):106245.

18. Sakaue M, Ohsako S, Ishimura R, Kurosawa S, Kurohmaru M, Hayashi $\mathrm{Y}$, et al. Bisphenol-A affects spermatogenesis in the adult rat even at a low dose. J Occup Health. 2001;43(4):185-90.

19. Tiwari D, Vanage G. Mutagenic effect of bisphenol A on adult rat male germ cells and their fertility. Reproductive Toxicol. 2013;40:60-8.

20. Bancroft JD, Stevens A. Theory and practice of histological techniques. Churchill Livingstone. 1997:10-45.

21. Khojasteh SMB, Sheikhzadeh F, Mohammadnejad D, Azami A. Histological, histochemical and ultrastructural study of the intestine of rainbow trout (Oncorhynchus mykiss). World Applied Sci J. 2009:6:1525-31.

22. Bozzola JJ, Russell LD. Electron microscopy: principles and techniques for biologists. Jones \& Bartlett Learning; 1999

23. Akingbemi BT, Sottas CM, Koulova AI, Klinefelter GR, Hardy MP. Inhibition of testicular steroidogenesis by the xenoestrogen bisphenol $\mathrm{A}$ is associated with reduced pituitary luteinizing hormone secretion and decreased steroidogenic enzyme gene expression in rat Leydig cells. Endocrinology. 2004;145(2):592-603. doi:10.1210/en.20031174. [PubMed: 14605012]

24. Lee HJ, Chattopadhyay S, Gong EY, Ahn RS, Lee K. Antiandrogenic effects of bisphenol A and nonylphenol on the function of androgen receptor. Toxicol Sci. 2003;75(1):40-6. doi: 10.1093/toxsci/kfg150. [PubMed: 12805653].

25. Salian S, Doshi T, Vanage G. Perinatal exposure of rats to Bisphenol A affects the fertility of male offspring. Life Sci. 2009;85(21-22):742-52. doi: 10.1016/j.lfs.2009.10.004. [PubMed: 19837096].

26. vom Saal FS, Cooke PS, Buchanan DL, Palanza P, Thayer KA, Nagel SC, et al. A physiologically based approach to the study of bisphenol A and other estrogenic chemicals on the size of reproductive organs, daily sperm production, and behavior. Toxicol Ind Health. 1998;14(1-2):23960. [PubMed: 9460178].

27. Nagel SC, vom Saal FS, Thayer KA, Dhar MG, Boechler M, Welshons WV Relative binding affinity-serum modified access (RBA-SMA) assay predicts the relative in vivo bioactivity of the xenoestrogens bisphenol $\mathrm{A}$ and octylphenol. Environ Health Perspect. 1997;105(1):70-6. [PubMed: 9074884].

28. Herath CB, Jin W, Watanabe G, Arai K, Suzuki AK, Taya K. Adverse effects of environmental toxicants, octylphenol and bisphenol A, on male reproductive functions in pubertal rats. Endocrine. 2004;25(2):163-72. doi: 10.1385/ENDO:25:2:163. [PubMed: 15711031].

29. Takao T, Nanamiya W, Nagano I, Asaba K, Kawabata K, Hashimoto K Exposure with the environmental estrogen bisphenol A disrupts the male reproductive tract in young mice. Life Sci. 1999;65(22):2351-7. [PubMed: 10597890].

30. Al-Hiyasat AS, Darmani H, Elbetieha AM. Effects of bisphenol A on adult male mouse fertility. Eur J Oral Sci. 2002;110(2):163-7. [PubMed: 12013561]

31. Matthews JB, Twomey K, Zacharewski TR. In vitro and in vivo interactions of bisphenol A and its metabolite, bisphenol A glucuronide, with estrogen receptors alpha and beta. Chem Res Toxicol. 2001;14(2):149-57. [PubMed: 11258963]. 
32. Tohei A, Suda S, Taya K, Hashimoto T, Kogo H. Bisphenol A inhibits testicular functions and increases luteinizing hormone secretion in adult male rats. Experiment Biol Med. 2001;226(3):216-21.

33. Hiort O. Androgens and puberty. Best Pract Res Clin Endocrinol Metab. 2002;16(1):31-41. doi: 10.1053/beem.2002.0178. [PubMed: 11987896].

34. Keri RA, Ho SM, Hunt PA, Knudsen KE, Soto AM, Prins GS. An evaluation of evidence for the carcinogenic activity of bisphenol A. Reprod Toxicol. 2007;24(2):240-52. doi:10.1016/j.reprotox.2007.06.008. [PubMed 17706921].

35. Ema M, Fujii S, Furukawa M, Kiguchi M, Ikka T, Harazono A. Rat twogeneration reproductive toxicity study of bisphenol A. Reprod Toxicol. 2001;15(5):505-23. [PubMed: 11780958].

36. Risbridger G, Wang H, Young P, Kurita T, Wang YZ, Lubahn D, et al. Evidence that epithelial and mesenchymal estrogen receptoralpha mediates effects of estrogen on prostatic epithelium. Dev Biol. 2001;229(2):432-42. doi:10.1006/dbio.2000.9994. [PubMed: 11150243].

37. Aikawa H, Koyama S, Matsuda M, Nakahashi K, Akazome Y, Mori T. Relief effect of vitamin A on the decreased motility of sperm and the increased incidence of malformed sperm in mice exposed neonatally to bisphenol A. Cell Tissue Res. 2004;315(1):119-24. doi: 10.1007/s00441003-0806-1. [PubMed: 14557871].

38. Meeker JD, Ehrlich S, Toth TL, Wright DL, Calafat AM, Trisini AT, et al. Semen quality and sperm DNA damage in relation to urinary bisphenol
A among men from an infertility clinic. Reprod Toxicol. 2010;30(4):5329. doi:10.1016/j.reprotox.2010.07.005. [PubMed: 20656017].

39. Qiu LL, Wang X, Zhang XH, Zhang Z, Gu J, Liu L, et al. Decreased androgen receptor expression may contribute to spermatogenesis failure in rats exposed to low concentration of bisphenol A. Toxicol Lett. 2013;219(2):116-24. doi: 10.1016/j.toxlet.2013.03.011. [PubMed: 23528252].

40. Iida H, Maehara K, Doiguchi M, Mori T, Yamada F. Bisphenol A-induced apoptosis of cultured rat Sertoli cells. Reprod Toxicol. 2003;17(4):457-64. [PubMed: 12849858].

41. Fiorini C, Tilloy-Ellul A, Chevalier S, Charuel C, Pointis G. Sertoli cell junctional proteins as early targets for different classes of reproductive toxicants. Reprod Toxicol. 2004;18(3):413-21. doi: 10.1016/j.reprotox.2004.01.002. [PubMed:15082077].

42. Li MW, Mruk DD, Lee WM, Cheng CY. Connexin 43 is critical to maintain the homeostasis of the blood-testis barrier via its effects on tight junction reassembly. Proc Natl Acad Sci US A. 2010;107(42):17998-8003. doi: 10.1073/pnas.1007047107. [PubMed: 20921394].

43. Wu HJ, Liu C, Duan WX, Xu SC, He MD, Chen $\mathrm{CH}$, et al. Melatonin ameliorates bisphenol A-induced DNA damage in the germ cells of adult male rats. Mutat Res. 2013;752(1-2):57-67. doi: 10.1016/j.mrgentox.2013.01.005. [PubMed: 23402883]. 